\title{
TTR
}

Traduction, terminologie, re?daction

\section{Pragmatics and Translation: the Problem of Presupposition}

\section{James F. Ehrman}

Volume 6, numéro 1, 1er semestre 1993

L'Histoire en traduction

URI : https://id.erudit.org/iderudit/037142ar

DOI : https://doi.org/10.7202/037142ar

Aller au sommaire du numéro

Éditeur(s)

Association canadienne de traductologie

ISSN

0835-8443 (imprimé)

1708-2188 (numérique)

Découvrir la revue

Citer cet article

Ehrman, J. F. (1993). Pragmatics and Translation: the Problem of Presupposition. TTR, 6(1), 149-170. https://doi.org/10.7202/037142ar d'utilisation que vous pouvez consulter en ligne.

https://apropos.erudit.org/fr/usagers/politique-dutilisation/ 


\title{
Pragmatics and Translation: the Problem of Presupposition
}

\author{
James F. Ehrman
}

\section{Introduction}

This study addresses the pragmatic dimension in the process of translation. Although there is no one undisputed definition of pragmatics, the term will be understood in its broadest sense as the relationship between language structure and extra-linguistic context (Levinson, p. 9). In this relationship, presupposition functions to specify the meaning of a linguistic expression by appealing to the context in which it is embedded. By specifying a level of meaning that is context-dependent, pragmatics concentrates on how linguistic expressions are encoded by their context (Levinson, p. 8). Within this domain there are a number of ways to investigate pragmatic relationships such as speech act theory, conversational implicature, deixis, and presupposition. However, within the framework of this investigation, the specific focus is the problem of presupposition and its consequences for both the production and reception of a translation.

Presupposition refers to those pragmatic inferences or assumptions which seem to be built into linguistic expressions and can be isolated by linguistic texts (Levinson, p. 68). According to this definition, presupposition relates linguistic structure to extra-linguistic context in terms of the inferences which can be 
made about this context from the linguistic structure itself. As a relationship between linguistic expression and extra-linguistic context, presupposition differs from logical entailment, which refers to those inferences which can be made strictly from the linguistic expression itself and are restricted to the truthconditions of the expression. In the sentence

Fred regrets not having received a university fellowship,

the only truth-conditional inference which can be made is that Fred did not receive a university fellowship. However, the verb "regret" indicates that Fred wanted a university fellowship; otherwise, the verb would be inappropriate. Since he regrets not having received a university fellowship, it can be presupposed that he wanted it. That Fred wanted a university fellowship is not equivalent to Fred's not having received a university fellowship and this is the distinction between logical-entailment and presupposition.

\section{The Relationship between Presupposition and Translation}

Because of this capacity to relate contextual information to linguistic structure, presupposition is particularly useful for the study of translation. In its most fundamental sense, translation is concerned with capturing the meaningful components in an original text in order to reconstruct them in a text of the target language (De Vasconcellos, p. 1). Although the concept of constructing a translated text on the basis of meaningful equivalence to the original seems almost truistic, its application in practice becomes problematic. The main problematic area is the notion of "meaningful equivalence," which has given rise to numerous debates among translation theorists. Central to this debate is whether the notion of meaningful equivalence should be expanded from formal semantics to include contextual factors of the communicative situation in which translations are made.

The debate on this notion of meaningful equivalence has resulted in a major shift in the focus of translation studies. Characteristic of this revision is the movement from prescriptive 
to descriptive approaches to translation (Hermans, p. 13). The main difference between these two approaches is one of orientation. A prescriptive approach proceeds from notions of how a translation should be made to the construction of a translation itself, with the result that theory precedes translation. In a descriptive approach the investigation begins with how a translation has been made; a theory is then constructed on the basis of this investigation. The more recent approaches in the field of translation have been descriptive because they focus upon the actual practice of translation within a specific historical context (Lambert and Van Gorp, p. 42).

The impetus for this change in orientation has been the emphasis on context-dependent rather than context-independent meaning in a text. A descriptive approach will first establish a framework to capture context-dependent meaning, whereas a prescriptive approach will first attempt to isolate a reader/translator-independent dimension of meaning in a text. This objective dimension will then be used as a basis for establishing equivalences by which the translation will be constructed. Such a basis is usually developed in terms of formal semantics because this linguistic level considers context-invariant meaning. A prescriptive approach presumes objectivity as the legitimacy criterion and its goal is to preclude any subjective, mediating influences of the translator.

Unfortunately, designating formal semantics as the single criterion on which a translation is to be evaluated is arbitrary and based on unproven theories which bifurcate language into an abstract mental component and a tangible phonological component (Wilss, p. 80). Moreover, focusing strictly on notions of formal semantics ignores points at which source text and translation deviate in terms of their information content. Rather than dismissing changes in information as subjective and nonessential for translation, such deviation becomes the point of departure for descriptive approaches to translation. In comparing an original text with its translation, how and why these differ becomes the object of investigation. Concentrating on this domain precludes prescriptive notions of correctness and incorrectness 
and frees the translation theorist from restrictions on the range of what is to be investigated in translation. The goal of the descriptive approach is to determine the relevant factors in the process of translation and to explain how they function to govern both the production and reception of a translation. A focus on the translation of presuppositions is consistent with this objective because they indicate relationships between text and context.

\section{Goal and Method of Investigation}

Because it is constituted by a relationship between text and context, presupposition is a powerful means to investigate contextual factors impacting upon the process of translation. This investigation will use presupposition to measure the epistemological context and its influence on the translation process. Accordingly, this investigation will focus on the structures of knowledge in both the original text and its translation. To investigate these structures of knowledge, presupposition will be used to determine what ideas constitute the conceptual framework informing the composition of a text. In an epistemological context this framework can best be understood in the sense of paradigm, as the term is used by historians of science. The term paradigm was coined by Thomas Kuhn to show

how, at a given period, thinking about a particular subject is commonly conditioned by some more or less coherent system of ideas which act, not so much as explicit tenets of a scientific theory, but as unspoken assumptions about the range of possible hypotheses which the scientist may entertain (Sampson, p. 15).

Because a paradigm is implicit rather than explicit, it can be understood as a set of assumptions which have been incorporated into an abstract model both to explain observable phenomena and govern what is possible and impossible with respect to these phenomena.

As an abstract model, the concept of paradigm derives from an over-arching perspective by which a culture understands 
itself and its environment. This perspective is influenced particularly by social and intellectual developments and can be expected to change along with these developments. Since presupposition is a way to infer the composition of this framework, changes in presupposition indicate changes in the conceptual frameworks which contextualize both original text and translation. Such changes are not necessarily arbitrary, nor do they necessarily reflect that the translator simply erred in translation. These changes in presupposition rather indicate changes in the way the information of the original text is understood in the context of the translation. If certain background concepts which contextualize the original text are no longer operative in the historical context of the translation, they might well be deleted. Moreover, the conceptual framework informing the process of translation might well be constituted by new ideas, with the result that new presuppositions may be introduced into the translation. Because of this link between presupposition and conceptual assumptions, changes in presupposition can point to variation in the conceptual frameworks of the original and the translation.

The goal of this comparison is to use presupposition to proceed inductively from linguistic expressions in the text to conceptual structures outside of the text. By relating text and context, presupposition provides a junction between conceptual structures inside the text and conceptual structures in its historical context. For this reason changes in presupposition between the original text and the translation do not necessarily indicate error in translation but rather a shift in understanding. Moreover, this shift in understanding can be specified in the changes in the respective historical contexts.

In this way, the actual comparison is between historical contexts and their respective conceptual frameworks. Where no change has been introduced into this framework an understanding of the original can be expected to be maintained in the translation. However, developments in the historical distance between the composition of the original and the translation will lead to changes between their respective 
conceptual frameworks. Consequently, changes in understanding can be expected at those points where these conceptual frameworks deviate significantly. Furthermore, such changes will be indicated by the deletion or addition of presuppositions in the texts.

To concentrate specifically on the conceptual dimension, the two texts which will be compared are scientific rather than literary. The selection of scientific texts is preferable because these texts have generally been thought to be free from the rhetorical considerations of literary texts. Literary works, tradition holds, are particularly characterized by their subjectivity and require at least a certain amount of interpretation. Because of this interpretation, a translation can be expected to diverge from the original ${ }^{1}$ in at least some respects. A scientific text, on the other hand, has been generally understood to be "factual" rather than fictitious and for this reason is not considered subject to the same interpretive requirements as a literary text.

By precluding the need for interpretation, translation of scientific information has been assumed to involve formal semantic equivalence, because, as fact, the meaning of the information is invariant. This investigation will refute this assumption because it will show that factual texts are also subject to interpretive requirements, although these might be different from literary interpretive requirements. Interpretation of a scientific work lies in the understanding of the concepts which have informed the work. Using presupposition to compare the conceptual frameworks of an original text and its translation will show that, where certain concepts qua facts are not understood, the information content of the translation is significantly altered.

1. The issue of divergence of course begs the issue of some benchmark by which it can be measured, particularly in the case of an interpretive work. However, establishing the basis for normative readings by which to measure deviation is a hermeneutic task beyond the scope of this study. 


\section{The Texts and Their Contexts}

The original text which will be investigated was written by Theophrastus von Honenheim or, as he is often known, Paracelsus (1493-1541). The text is the second tract from his work entitled Liber de nymphis, sylphis, pygmaies et salamandris et de caeteris spiritibus [Book of nymphs, sylphs, pygmies, salamanders and related spirits]. This work is useful for an investigation into the epistemological dimension of translation because it presents an excellent example of Paracelsus' way of thinking (Blaser, p. 6). The translation is by Manly Palmer Hall and was first printed in 1964. As this date indicates, Hall's thinking was informed by the conceptual framework of the post-eighteenth century. To understand the consequences of the historical distance between the composition of the original and of the translation, it is necessary first to summarize the key points of the conceptual frameworks operative in each of these periods.

In the conceptual framework of the early sixteenth century, the primary governing concept is the notion of the organic universe. Assumptions about this organic universe were not based on inferences made from empirical investigations, but rather on the speculations of natural philosophers dating back to antiquity. Perhaps the most significant of these concepts is that all manifestations of the material universe constitute a multiplicity deriving from an underlying unity. This underlying unity is called the Prima materia from which matter is created. Prima materia as the unified substance underlying all substances is not matter strictly speaking, but rather a potentiality which is actualized by taking on form.

Consequent to the union of prima materia and form, matter is manifested at its most basic level as an element. As the primary level of manifestation, an element can be understood as that which makes prima materia concrete. There are four elements: 1) earth, which has the two properties of being cold and dry; 2) water, which as the two properties of being cold and wet; 3) air, which has the two properties of being hot and wet; 4) fire, which has the two properties of being hot and dry. Although elements 
are not considered to be capable of further division, they are regarded as transmutable. By virtue of the property two elements share, the one may be transmuted into the other. For this reason, earth, having the properties of cold and dry, may be transmuted into water, having the properties of cold and wet, through the shared property of coldness.

A significant consequence of this way of thinking is the division of the universe into microcosm and macrocosm. Man is conceived as constituted in some measure by each of the four elements and for this reason contains all levels of being within himself (Conger, ch. xiii). Moreover, the macrocosm and microcosm are linked together by a series of sympathies or correspondences. Through these analogical relationships all existing parts of the universe, seen and unseen, are related. For this reason the analogical correspondences found in nature are not regarded as descriptive comparisons but rather as essential relationships. Consequently, outward resemblance is a sign of inward ontological connection (Bosky, p. 61).

Against this paradigm of the organic universe, a competing paradigm developed out of the scientific revolution of the seventeenth century. This paradigm was derived from empirical approaches to science and is based on the notion of a mechanistic universe governed by laws. Being governed by natural laws, the phenomena of nature are placed into a framework in which they can inevitably be explained by empirical experiment. The primary criteria by which an experiment is judged valid is that it be repeatable, verifiable, and subject to prediction. In this way, the workings of nature are limited to explanations in terms of linear causality. Consequently,

... all the phenomena could be described by simple, deterministic laws of force and motion so that all future states of the world could in principle be inferred from a complete knowledge of its present state... (Sampson, p. 15)

There was an intentional attempt on the part of the empiricists to systematically disprove the conceptual assumptions on which 
earlier notions of the universe were based. As a result of this attempts, empirically derived models gained ascendancy in Europe around the beginning of the seventeenth century. ${ }^{2}$ Consequently, the Hall translation of Paracelsus' text was made in a historical context governed by a conceptual framework entirely different from that of the original.

\section{Analysis}

In the following analysis Hall's translation will be segmented into the paragraphs by which he organized his text. Following each of Hall's paragraphs will be the corresponding paragraph (or paragraphs) from Paracelsus' text. The presuppositions in the texts will then be extracted and placed into their respective conceptual frameworks. In this way, comparison will actually be performed on the level of context to determine where concepts have been retained, deleted, or added between the original and the translation.

Hall titles this chapter of his translation Their Habitation and Government and the first paragraph begins:

The habitations of the elementals vary according to the element in which they exist; that is, air, fire, water, or earth. The people of the water are called nymphs; those of the air, sylphs; of the earth, pygmies; and of the fire, salamanders. But more correctly the water elementals should be called undines; the air people sylvestres; those of the earth and mountains, gnomes; and the people of the fire, vulcani rather than salamanders (Hall, p. 70).

The title of Paracelsus' second tract is Von jher Wohnung and begins:

2. The turn towards empirically based models did not happen at a constant rate but, for example, occurred earlier in England and somewhat later in Germany. 
Jhr Wohnung sind viererley / das ist / nach den Vier Elementē / Einesser / Eine im Lufft / Ein in der Erden / Eine im Fewr, Die im Wasser sind Nymphen / die im Lufft sind Sylphen / die in der Erden sind Pygmaei / die im Fewr Salamandrae. Nun aber / daz sie recht Namen haben / das ist nicht sondern solch Nammen so ich do furhalt / dieselbigen Nammen sind geben worden von denen / die sie nicht erkennt haben. Dieweil sie aber die ding bedeutten /vnd durch die Nammen mogen verstanden werden / so laß ichs dobey auch bleiben. Wiewol von Wasserleuten Vndina der Nam auch ist / vnnd von den Lufftleuten Syluestres / vnnd von den Bergleuten Gnomi unnd vom Fewer mehr Vulcani als Salamandri; Jedoch wie dem ist / wie es mag verstanden werden mit der vnterscheyed / do bleibts bey (Blaser, pp. 16-17).

Hall's translation of this passage is not constituted by any linguistic expressions which are presuppositions. As a result, there is no linguistic expression which is structurally embedded in the conceptual framework of the context. However, there is one linguistic expression in the original passage by Paracelsus which presupposes information. The sentence "Dieweil sie aber die ding bedeutten / vnd durch die Nammen mogen verstanden werden / so laß ichs dobey auch bleiben" presupposes an ontological relationship between name and object. This ontological relationship is established by the conjunction "dieweil," or "because," and is a presupposition because it refers to background knowledge in which this kind of ontological connection is considered valid. The truth-conditional analysis of this sentence is that objects are understood by their names. This truth-conditional analysis is derived solely from the linguistic expression and does not make any statement about the validity of the claim. However, the use of the conjunction "dieweil" refers the linguistic expression to an already known, contextual framework which assumes the validity of ontological connections between words and the objects to which they refer. Otherwise, the use of "because" would be inappropriate, for this ontological connection would have to be first established itself. Since the conjunction "because" is used to frame the clause in which an 
object is understood by its name, an ontological relationship between a thing and its name is presupposed.

The deletion of this presupposition in the Hall text is explainable in terms of the disparity in the historical contexts between the two texts. An ontological relationship between a word and the object which it names is not a part of the conceptual framework in which Hall wrote his translation. According to more modern linguistic theories, there is an arbitrary relationship between the linguistic sign and its referent. Although the relationship between a word and the object to which it refers may be necessary in terms of convention (Benveniste, p. 45), there is otherwise no unseen or metaphysical connection or relationship.

Such a relationship was, however, permissible in the conceptual framework which informed the thinking of Paracelsus. The essential connection between a name and the object to which this name refers is one consequence following from the notion that the universe is constructed out of analogical relationships. This essential connection is indeed necessary for verbal conception because it provides a theoretical framework for the development of names and of language itself. According to this way of thinking, an invisible, metaphysical reality gives rise to both the object and the name, which are apparently discreet only in the physical world. As a result, the name and the physical object to which the name refers are both consequences of the metaphysical reality which precedes and underlies both of them. In this way the notion of a name as descriptive is inverted since the description is arrived at precisely because of its essential connection to the object. In other words, verbal conception is not possible except through this ontological relationship.

Because this notion of ontological relationship between name and object is alien to the conceptual framework of a nineteenth and twentieth century readership, it is conceivable that Hall either did not understand it himself, or did not believe that his readership would understand it. Due to the possibility of 
misunderstanding, he elected to delete the claim in its form as a presupposition. He does maintain the information which follows the claim, namely, that the elementals should "more correctly" be referred to by other names. However, there is no rationale for why one set of names is more correct than any other, and as a result the status of more correctly naming the elementals changes from a presupposition to an assertion.

The next paragraph in the Hall text begins to describe the relationships of the elementals to humanity and to each other. The paragraph reads:

Each race of elementals remains confined to its own element. The water people have no dealings with the ones of the earth; nor the fire people with those of the air. Each race lives by itself and never associates with the other elementals. Only to man are they drawn, appear to him at times, and serve him so that he may recognize God in his wonderful creation and learn how all elements are peopled and ruled by divine law. The elementals existing in each of the four elements differ from one another in person, character, species, and habitation, yet they all resemble man (Hall, p. 70).

The Paracelsus text does not make a paragraph break here but continues directly from the preceding passage:

Nun aber so wissen / so jhr Regiones beschrieben sollen werden / so mussen sie auch getheylt werden inn jhr Theyl: Dann die Wasserleuth haben kein geschefft mit den Bergleuthen / die Bergleuth auch nicht mit jhnen / also die Syluestres / vnd also auch die Salamander: Jedliches hatt sein besonder Wohnung / aber dem Menschen dem erscheinen sie wie obsteht / das er erkenn vnnd sech / wie wunderbarlich GOTT sey inn seinen Wercken / das er kein Element feyern leßt / vnnd leer leßt / er hab doch grosse Wunderwecken inn jhnen. Also auff solches folgen hernach Vier Regiones / vnnd der Wohnung / auch inn der Person / Wesen / vnnd Artt / wie weit sie sich von einander scheyden / vnnd doch dem Menschen gleichformiger / 
dann sie selbst einander / vnnd doch all Menschen / wie im Ersten Tractat begriffen ist (Blaser, p. 17).

Comparing these two passages reveals that there is a presupposition in the Paracelsus text which has been deleted in the Hall text. This presupposition is indicated by the word "dann," which means "because" or "for." In the context of the passage itself the word "because" conjoins a clause which explains the rationale for dividing the elementals into their parts. An English paraphrase of the passage reads:

Know that, just as their locations should be described, so must they be divided into their parts. For the people of the water have no dealings with the people of the mountains, nor the mountain people with them. The same is true for the Sylvestres and the Salamanders.

The presupposition here is the reason why the respective elementals do not interact with one another; otherwise, introducing the clause with the conjunction "because" or "for" would be illogical because it would provide no causal basis for dividing the elementals into their respective categories as it does.

This presupposition governing the division of the elementals is the relationship among the elements themselves. These constitute the first level of manifestation following the union of spirit and matter and are not capable of further subdivision. As such they are the foundations upon which further manifestations are constructed. Because they are not capable of further division, they do not themselves mix together. Consequently, the elementals which dwell in each of the four elements also cannot mix with each other because to mix would be to violate their status as elementals. Hall does not keep the passage stating that the elementals must be divided into their parts. Rather, he deletes this information and restates the rationale for this division in the form of an assertion: "Each race of elementals remains confined to its own element." By deleting the requirement to divide the elementals into their categories, he effectively deletes the presupposition concerning the relationships obtaining between the four primary elements. These relationships 
were an integral part of the conceptual framework of Paracelsus' time, but they have not been a part of the conceptual framework since the eighteenth century. Consequently, it can again be inferred that either Hall did not understand the presupposition or believed it would confuse his readership. Due to the potential for confusion, this deletion of a presupposition and the restatement of information which logically follows from it can be ascribed to the change in historical context.

The final passage from the Hall text reads:

We recognize the four elements and know that the man from Adam can exist and live only in air, which surrounds him as water surrounds the fish. Each elemental is created for its proper element. To the nymphs, the water is what air is to man. And as man wonders how the nymphs can live in the water, so do they wonder that man can live in the air (Hall, p. 70).

The corresponding passage from Paracelsus reads:

Nun wie jhr wissen / dass Vier Element seind / der Lufft / Wasser / Erden vnnd Fewr: Nun wissen jhr / daß wir Menschen auß Adam im Lufft stehnd und gehnd / und seind mit jhm vmbgeben / wie ein Visch mit seim Wasser: Vnd als wenig mogen wir ohn denselbigen sein / als ein Visch ohn Wasser. Nun wie der Visch im Wasser sein Wohnung hatt / vnd das Wasser ist an dem ortt sein Lufft dorinn er wohnt: Also ist dem Menschen der Lufft in sein Elementen beschaffen / dorinn zuwandern. Nach dem Exempel verstanden die Vndenen / daß sie im Wasser wohnen / vnnd das Wasser ist jhnen gleich geben als vns der Lufft; vnd wie wir vns verwundern / daß sie im Wasser sollen sein / so verwundern sie ob vns / im Lufft zu sein (Blaser, p. 17).

There is one presupposition in the Hall text with a corresponding presupposition in the Paracelsus text. This presupposition is set off by the factive verb "know" and reads: "know that the man from Adam can exist and live only in air..." 
The corresponding presupposition in the Paracelsus text is also set off by the factive verb "know" and reads: "Nun wissen jhr / daß wir Menschen auß Adam im Lufft stehnd und gehnd..." In both instances, the presupposition is that man exists/lives in the air. One reason why this presupposition has been retained in the translation is that it does not involve an overt change in conceptual framework. That human beings exist, as it were, in the air, as opposed to the water, is not really a problem of conception. The conlusions which a sixteenth century reader vis a vis a seventeenth century reader might draw may indeed have been different, but the presupposition as such is not a problem for translation.

The translation problem results from the information conveyed by an additional presupposition of the Paracelsus text such that is again undergoes a change in status from presupposition to assertion. This presupposition is also indicated by the factive verb "know" and reads in the context of the passage: "Nun wie jhr wissen / dass Vier Element seind / der Lufft / Wasser / Erden / vnnd Fewr." Through the use of a factive verb the reader is referred back to the presupposition that there are four elements which are air, water, earth and fire. Hall's translation of this line reads: "We recognize the four elements..." and makes no factive reference at all. If the passage has stated that "we recognize that there are four elements," then the verb "recognize" would have been used in the factive sense. However, as used in this context "recognize" is similar to "posit" and could be rephrased: "we posit the four elements." In this sense "recognize" is used to introduce something new, ergo the necessity for recognition, and has the status of an assertion.

It may be argued that the act of recognition requires an object to be recognized and for this reason presupposes the object of recognition. In this way, "recognize" would in fact be used in the sense of "recognize that." However, if that were the case, the question arises as to why the verb was not used in an overtly factive sense because there is no syntactic necessity preventing this usage. In fact, using the verb in this way by stating "recognize that" would be syntactically closer to the original text. 
Moreover, it cannot be unequivocally specified that the verb should be understood in this sense, because it is just as easily interpreted as an assertion. For this reason, arguments supporting a factive use of "recognize" are weakened.

Because the use of the verb "recognize" is assertive rather than factive, a strong case can be made for the statement that, in this instance, a change in conceptual framework resulting from historical distance has again informed the construction of the translation. As previously discussed, the concept of the four primary elements belongs to a pre-empirical conceptual framework. Since it is embedded in this older thinking, this concept is unsuited as a presupposition in an empirically oriented conceptual framework. Owing to this unsuitability, it can be expected that this concept would be introduced in the form of an assertion for a modern readership. Presenting this concept as a presupposition would have been confusing to a readership not familiar with the general pre-empirical conceptual framework and might have affected the reception of the translation.

\section{Conclusion}

Each of these three examples demonstrates a pattern in which certain information conveyed in the original text by means of presupposition undergoes a change to the status of assertion in the translation. This change in status is brought about by deleting the presupposition and then restating the information consequent to the presupposition in the form of an assertion. There is no grammatical or syntactic necessity whatsoever for this change in status. Hall could just as well have constructed his translation on the basis of some formal equivalence in which the presuppositional structure is maintained.

The significance of his deletion of presupposition can be assessed in two ways: arbitrary or intentional. If the deletion of presupposition is arbitrary, no valid inferences about the process of translation can be drawn. However, the consistent pattern which becomes evident in the Hall translation strongly suggests 
that the deletion of presupposition is not arbitrary. Each deletion of presupposition in the translation occurs specifically at that point at which the presupposed information is embebbed in the conceptual framework of the sixteenth century. Consequently, presuppositions are deleted where the presupposed information is inconsistent with the conceptual framework of the posteighteenth century.

The regularity of this parallel between the deletion of presupposition and the change of conceptual framework strongly suggests a causal connection between understanding and the decision to delete certain presuppositions. The term "understanding" is used here in the general sense of mental comprehension and refers to the apprehension of general relations of particulars (Woolf, p. 1267). As a result the decision to delete presuppositions embedded in the context of a sixteenth century conceptual framework is governed by a change in understanding which derives from the change to a posteighteenth century conceptual framework. To avoid confusion or misunderstanding that might arise from this inconsistency, Hall intentionally opted to delete these presuppositions. Changes in information between original and translation are not arbitrary but follow from a change in understanding on the part of the translator, who is translating in a new historical context and consequently within a new conceptual framework.

Showing the consequences of changes in understanding on the translation of a factual text raises a number of hermeneutic issues. The first concerns the ability of the linguistic element itself to convey signification which has its locus in the context, rather than the text itself. Using presuppositions to infer components of what can be called a conceptual framework, the comparison of presuppositions between an original text and its translation is tantamount to a comparison of the conceptual frameworks in which each text is embedded. By making a comparison on this level, changes in conceptual framework can be expected to result in changes of information between original and translation as measured by the use or absence of presupposition. 
Since concepts change over time, it seems that factual discourse is to a large extent subject to interpretive requirements similar in principle to those of fictional discourse. Even though there is no grammatical or syntactic necessity preventing a more "literal translation," a "conceptual necessity" seems to have governed the construction of the translation. This conceptual necessity arises because the conceptual structure which informs certain linguistic expressions of the original text are simply not present in the context of the translation. Due to these gaps in conceptual structure a new or different understanding is brought to bear on the information of the text. In this way some information will be misunderstood or not understood at all. As a result the translator is faced with the problem of dealing with the new understanding a new readership will bring to the translation.

How the translator deals with this problem raises the issue of the naive and informed translator. A naive translator is one who does not know to account for shifts in understanding resulting from changes in conceptual framework. The naive translator can therefore be expected to introduce changes into the translation vis-à-vis the original because these changes may not be grasped as such. In this way, any hermeneutic process of recontextualization is circumvented, or rather omitted. Consequently, information in the original which is not understood by the translator is either deleted or changed to fit the norms of contemporary understanding. For this reason, a naive translation introduces the original into a new context but strips it of its own context.

An informed translator, on the other hand, could be expected to re-contextualize the translation by attempting to compensate for changes in conceptual framework between original and new contexts. One way to do this might be to "gloss" the translation by overtly including presupposed information along with the translation itself. Such information could be included either in the body of the translation or in footnotes. In this way the reader can make up for deficiencies in contextual 
information and thus obtain a better understanding of the translation. By adding otherwise presupposed information, an informed translation introduces an original text into a new context with some attempt to keep the original context intact.

One could argue that Hall did not do his "hermeneutic homework" because he does not seem to have made any attempt to recontextualize those concepts with which a nineteenth century reader would be unfamiliar. Since such re-contextualization is lacking, it might be concluded that Hall is a naive translator. However, this conclusion is actually premature because it cannot be determined whether Hall himself was unfamiliar with the conceptual framework of the sixteenth century and hence did not fully understand the presuppositions of the text, or whether he determined that this framework would be confusing for his readership. If the latter is the case, he may have intentionally constructed his translation with the objective of making it as accessible as possible to a post-eighteenth century readership by eliminating potential points of confusion. By making his translation as accessible as possible to a new readership, Hall introduces the Paracelsus text outside of its sixteenth century conceptual framework.

Evaluating Hall's strategy involves the issue of determining what is to be evaluated and a standard by which this can be measured. Any evaluation in terms of correct/incorrect is necessarily based on prescriptive notions which are themselves embedded in a particular context. If, for example, the standard is one of equivalence to the original text, then Hall's translation obviously falls short of the mark. However, there is no reason to make equivalence the basis for evaluation because equivalence in terms of formal semantics and syntax would involve introducing presuppositions predicated upon a conceptual framework unfamiliar to a post-eighteenth century readership. To avoid potential confusion that could result from this unfamiliarity, Hall opted to delete the presuppositions and subsequently to assert the information which follows from these presuppositions. This strategy makes sense from the standpoint of the reception of the translation and is itself 
revealing about the standards of the practice of translation during his time.

Recognizing that these standards of translation shift with changes in historical contexts is the basis for descriptive approaches to the study of translation. Functionally, these are more appropriate than limited prescriptive approaches because comparing differences between a translation and its original reveals something about the standards by which translations are both produced and received. Moreover, studying how standards of translation shift indicates changes in priorities and consequently points to developments in the historical context. In this endeavor the use of presupposition is particularly useful by virtue of its capacity to infer specific elements of context from structures in the text itself. In this way, inferences about the context are based on heuristic notions of periodization which are themselves subject to biases of context. Because of this empirical foundation, a pragmatic approach using presupposition significantly enhances the field of translation study through its use as an effective instrument of investigation.

University of Texas at Austin

\section{References}

BENVENISTE, Émile (1966). "The Nature of the Linguistic Sign," Problems in General Linguistics. Coral Gables, University of Miami Press, pp. 43-48.

BLASER, Robert, ed. (1960). Theophrastus von Hohenheim genannt Paracelsus: Liber de nymphis, sylphis, pygmaeis et salamandris et de caeteris spiritibus. Altdeutsche Übungstexte, Band 16. Bern, Francke.

BOSKY, Bernadette Lynn (1990). "Occultism and the Renaissance Outlook," Gnosis 14, pp. 61-67. 
CONGER, George, Perrigo (1967). Theories of Macrocosms and Microcosms in the History of Philosophy. New York, Russell and Russell.

DE VASCONCELLOS, Muriel Habel (1985). "Theme and Focus: Cross-Language Comparison via Translations from Extended Discourse." Diss. Georgetown University.

HALL, Manly Palmer (1964). Paracelsus: His Mystical and Medical Philosophy. Los Angeles, Philosophical Research Society.

HERMANS, Theo (1985). "Introduction: Translation Studies and a New Paradigm," The Manipulation of Literature: Studies in Literary Translation. Ed. Theo Hermans. London and Sydney, Croom Helm, pp. 7-15.

HOLMYARD, E. J. (1968). Alchemy. Harmondsworth and Middlesex, Penguin.

JACOBI, Jolande, ed. (1988). Paracelsus: Selected Writings. Trans. Norbert Guterman. Bollingen Series, 28. Princeton, Princeton University Press.

KÜHLWEIN, Wolfgang (1983). "Sociosemiotics Across Cultures," Language Across Cultures, Ed.Liam Mac Mathuna and David Singelton. Proceedings of a Symposium held at St Patrick's College, Drumcondra Dublin. 8-9 July. Irish Association for Applied Linguistics, pp. 5-19.

LAMBERT, José and Hendrik VAN GORP (1985). "On Describing Translations," The Manipulation of Literature: Studies in Literary Translation. Ed. Theo Hermans. London and Sydney, Croom Helm, pp. 42-53.

LEVINSON, Stephen (1983). Pragmatics. Cambridge, Cambridge University Press.

SAMPSON, Geoffrey (1980). Schools of Linguistics. Stanford, Stanford University Press. 
SNELL-HORNBY, Mary (1988). Translation Studies: An Integrated Approach. Amsterdam and Philadelphia, Benjamins.

VICKERS, Brian (1988). "On the Function of Analogy in the Occult," Hermeticism and the Renaissance: Intellectual History and the Occult in Early Modern Europe. Ed.Ingrid Merkel and Allen G. Debus. London and Toronto, Associated University Press, pp. 265-292.

WESTMAN, Robert S. and J.E. MCGUIRE, eds. (1977). Hermeticism and the Scientific Revolution. Los Angeles, William Andrews Clark Memorial Library.

WILSS, Wolfram (1977). Übersetzungswissenschaft: Probleme und Methode. Stuttgart, Ernst Klett.

WOOLF, Henry Bosley, ed. (1980). Webster's New Collegiate Dictionary. Springfield, G. \& C. Merriam. 